\title{
ASUMISPALVELUJEN HANKINNAN KEHYKSET
}

\section{Yhteistoiminnallista mallia etsimässä}

\section{Johdanto}

Vuosikymmen sitten mielenterveyskuntoutujien asumispalvelujen kaikista tuottajista noin 30 prosenttia oli osallistunut palvelujen kilpailutukseen (Salo \&t Kallinen 2007). Nyt sosiaali- ja terveyspalveluja hankitaan, kilpailutetaan, ulkoistetaan ja yksityistetään rutiininomaisesti. Kilpailutuksen piiriin kuuluu noin 90 prosenttia asumispalveluista. Vuonna 2005 asumisyksiköiden keskimääräinen koko oli alle 13 asukasta yksikköä kohti. Laskutavasta riippuen tutkijaryhmämme arvioi lukumäärän vähintään kolminkertaistuneen vuosikymmenen aikana ${ }^{1}$. Asukkaiden enemmistö muodostui pääosin entisistä psykiatrisista sairaalapotilaista. Nyt asukasprofiili on huomattavasti monimuotoistunut. Tutkimuksemme osoitti myös kuntoutumistulosten olleen merkittävästi heikompia yksiköissä, joihin oli sijoitettu ikäihmisiä, kehitysvammaisia ja mielenterveyskuntoutujia (ibid.).

Mielenterveyskuntoutujien asumispalveluissa merkittävin hallinnollinen muutos on ollut päätöksenteon siirtyminen psykiatrisen erikoissairaanhoidon lääkäreiltä kunnallisille sosiaalipalvelujen viranomaisille. Vuonna 1988 voimaan astuneessa sosiaalihuoltolaissa asumispalvelut määriteltiin osaksi sosiaalipalveluita (Sosiaalihuoltolaki 710/1982, 17§). Lain täytäntöönpano kesti poikkeuksellisen pitkään. Laissa sosiaali- ja terveydenhuollon suunnittelusta ja valtionosuudesta todetaan, että kunta voi järjestää sosiaali- ja terveyspalvelut "hankkimalla palveluja valtiolta, toiselta kunnalta, kuntainliitolta tai muulta julkiselta taikka yksityiseltä palvelujen tuottajalta" (L733/1992, 17§).

Vuoden 1994 alussa astui voimaan laki julkisista hankinnoista. Sen mukaan "(V)altion ja kuntien viranomaisten sekä muiden tässä laissa tarkoitettujen hankintayksiköiden on kilpailun aikaansaamiseksi sekä tarjousmenettelyyn osallistuvien tasapuolisen ja syrjimättömän kohtelun turvaamiseksi noudatettava hankinnassaan, mitä tässä laissa säädetään" (L1501/1992, 1§). Laki sosiaali- ja terveydenhuollon suunnittelusta ja valtionosuudesta tuottaa kunnallisen sosiaali- ja terveyspolitiikan autonomian mahdollisuuden, minkä laki julkisista hankinnoista suhteellistaa avaamalla kilpailun sosiaali- ja terveyspalvelujen tuotantoon "Euroopan talousalueesta tehdyn sopimuksen mukaisesti”. Näin ollen nämä lait sisältävät itsehallinnon osalta vastakkaisia pyrkimyksiä.

Sosiaalihuoltolain mukaan asumispalvelut ovat sosiaalihuollon avopalveluita, eivät enää laitoshoidollisen erikoissairaanhoidon jatketta. Päätöksenteko näyttää laajemmin siirtyneen sosiaalipalvelujen kunnallisille viranomaisille vasta hankintalain käyttöönoton jälkeen 2000-luvun alkuvuosina. Tämän jälkeen kunnalliset viranomaiset olisivat yhdenmukaisesti seuranneet uuden julkishallinnollisen

\footnotetext{
${ }^{1}$ Mielenterveyskuntoutujien asumispalveluita ei Suomessa ole tilastoitu. Arviomme perustuu viranomaistietoihin tutkimiltamme alueilta. Suurimmassa osassa yksiköistä oli 30-40 asukasta, mutta yli 50 asukkaan yksiköt eivät olleet poikkeuksellisia.
} 
johtamisen oppeja (Eräsaari 2006). Tässä artikkelissa osoitetaan, että uusia julkishallinnon oppeja on sovellettu toisistaan varsin poikkeavilla tavoilla.

Hyvinvointipalvelujen markkinaehtoistumisen aikakaudella julkisen päätöksenteon konteksti on muuttunut (Krachler \&t Greer 2015). Palvelutuotannolla vaurastumista pidetään asiaankuuluvana sivutuotteena palvelujen markkinaehtoistumisesta. Tarkasteltaessa kunnallisia sosiaali- ja terveyspolitiikan toteuttajia havaitaan, ettei suunnanmuutos ole ollut yhdensuuntainen eikä ristiriidaton. Lehdon ja Tynkkysen (2013) haastattelututkimuksen mukaan vain yksityiset palveluyrittäjät uskovat vahvasti yksityisen palvelutuotannon alentavan palvelujen hintoja sekä parantavan niiden laatua ja saatavuutta. Kunnallisen terveydenhuollon ja vanhuspalvelujen johtajat sekä poliittiset päätöksentekijät uskovat yksityisen palvelutuotannon parantaneen ennen muuta palvelujen saatavuutta. Vain alle puolet johtajistosta arvioi hankintojen vähentäneen kuntien kustannuksia, parantaneen palveluita ja lisänneen asiakastyytyväisyyttä. Sen sijaan selkeää näkemystä ei ilmaistu, miten yksityinen palvelutuotanto olisi vaikuttanut palvelujen laatuun ja asiakkaiden tyytyväisyyteen. (Ibid.)

Julkisten palvelujen markkinoistumista tutkineen Julian Le Grandin (2007) mukaan yksityisten palvelumarkkinoiden toimivuus edellyttää riittävää määrää keskenään kilpailevia palveluntuottajia, markkinoiden avoimuutta uusille kilpailijoille ja pelisääntöjä, jotka pakottavat kilpailussa hävinneet muuttamaan toimintaansa tai poistumaan markkinoilta. Julkisten palvelujen hankinnassa Le Grand pitää valintaa ja kilpailua tuloksellisempana vaihtoehtona kuin ammattilaisiin ja managereihin luottamista, hallintovallan käskyttämistä, käyttäjien äänen kuulemista tai heidän etujensa ajamista (ibid.).

Artikkelissa kuvaan, millaisia tavoitteita kunnalliset tilaajat asettavat hankittavil- le asumispalveluille ja kuinka he tavoitteiden toteutumista valvovat. Selvitän, millaisia asumispalvelujen tilaamisen kehyksiä tunnistettiin haastatteluaineiston perusteella. Lopuksi pohdin lyhyesti, miten Le Grandin palvelujen hankinnan analyysiä voitaisiin soveltaa tilaamisen kehyksissä. Artikkeli muodostaa suppean osan työn alla olevaa laajaa tutkimustani mielenterveystyön markkinaehtoistumisesta.

Kuvaan ensin tutkimuksen aineistot ja haastattelujen analyysimenetelmät. Tämän jälkeen esittelen tilaajien keskeiset tavoitteet asumispalveluille. Tilaajahaastattelujen kvalitatiivinen analyysi tuotti kolme toisistaan selvästi poikkeavaa tilaajien merkitysrakenteiden jäsennystapaa, joita nimitän kehyksiksi. Esitän tiivistetysti kehysanalyysin tulokset sekä kehysten vahvuuksien ja heikkouksien pohjalta rakennetun vaihtoehtoisen kehyksen pääpiirteet. Johtopäätöksissä hyödynnän tuloksia palvelujen markkinaehtoistumisen ja sosiaali- ja terveydenhuollon rakenneuudistuksen (sote) pohdinnassa.

\section{Tekijät, aineistot ja menetelmät}

Asumispalvelujen musta laatikko -hankkeessa kerättiin laaja haastatteluaineisto kolmelta seutukunnalta ${ }^{2}$ vuoden 2015 aikana. Kaupunkien väestöpohja vaihteli 80000 asukkaasta 300 000:een. Valinnassa kiinnitettiin huomiota siihen, että kaupungilla oli sopimus suurten tai keskisuurten palveluntuottajien kanssa, jotka toimivat eri puolilla Suomea. Kaupunkien tuli myös olla asumispalvelujen kilpailuttamisen eri vaiheissa (käynnistyvä hankintakierros; keskivaiheen sopimuskausi; päättynyt sopimuskausi). Tutkimusluvat haettiin kaupunkien viranomaisilta ja hallinnonalan eettisiltä toimikunnilta. Haastateltavien osallistuminen tutkimukseen oli vapaaehtoista ja anonyymiä. Litteroidusta aineistosta poistettiin haastateltavien tunnistetiedot. Alkuperäinen haastatteluaineisto on hankkeen vas-

\footnotetext{
2 Koneen säätiö rahoitti vuonna 2015 tutkimus- ja kehittämishanketta, jonka tutkijaryhmään kuuluivat VTT Tuukka Tammi (THL), toimittajat Antti J. Järvi ja Anu Silfverberg (Long Play Oy), kokemusarvioitsijat Tomi Kallio ja Nina Peltola sekä artikkelin kirjoittaja.
} 
tuullisen tutkijan hallussa ja asianmukaisesti säilytettynä.

Asumispalveluita ja niiden kehittämishaasteita kartoitettiin kunnallisten tilaajien kanssa. Kultakin asumispalvelun sopimusalueelta valittiin tutkimuskohteiksi kuusi asumispalvelutuottajaa. Valinnassa korostettiin markkina-asemaansa vahvistaneiden suurten yritysten osuutta, jotta palvelutuotannon oletettua rakennemuutosta voitaisiin analysoida. Tutkimukseen osallistui myös pienten ja keskisuurten yksityisten palvelutuottajien, kolmannen sektorin ja kunnallisia asumispalveluyksiköitä. Tutkijaryhmän jäsenet haastattelivat palvelujen tilaajia $(n=4)$, yrittäjiä $(n=18)$, palvelutuottajien aluejohtajia $(\mathrm{n}=4)$ sekä asumisyksiköiden johtajia ja vastaavia ohjaajia (n = 18). Yksiköiden työntekijöitä haastateltiin ryhmissä. Fokusryhmähaastatteluihin osallistui kolmesta seitsemään työntekijää, yhteensä noin 90 työntekijää. Tutkimuksessa haastateltiin 120 asumisyksiköiden asukasta. Noin sadan yksilöhaastattelun lisäksi tehtiin kolme asukkaiden fokusryhmähaastattelua.

Tutkijaryhmän kokoonpano poikkesi tavanomaisesta. Siihen kuului kaksi tutkivaa journalistia, kaksi koulutettua kokemusarvioitsijaa sekä kaksi mielenterveys- ja päihdetutkimukseen erikoistunutta yhteiskuntatieteilijää. Toisella kokemusarvioitsijalla on pitkäaikainen kokemus asumispalvelujen käytöstä. Tutkijaryhmä laati yhdessä teemahaastattelurungot. Kaikista haastatteluista noin 50 prosentissa oli kaksi tai kolme haastattelijaa. (Vrt. Hirsjärvi \&t Hurme 2001.)

Kolmeen tilaajahaastatteluun osallistui tilaajapäälliköiden lisäksi asumispalvelupäällikkö ja yhteen haastatteluun myös asumispalveluista vastaava sosiaalityöntekijä. Tein yhden vertailevan haastattelun tilaajapäällikön kanssa. Tilaajien teemahaastattelu muodostui neljästä pääaiheesta:

1. Asumispalvelujen tehtävät ja perustelut.

2. Asukkaiden toiminta- ja vaikuttamismahdollisuudet.

3. Asumispalvelujen hankinta.

4. Palvelujen tilaajat, yhteistyö palvelutuottajien kanssa ja palvelujen kehittäminen.
Artikkelin tilaajahaastattelut litteroitiin. Niiden kesto vaihteli runsaasta kahdesta tunnista kolmeen tuntiin. Haastattelijoita oli neljä (kerran), kolme (kaksi kertaa) ja yksi (kerran): yhdestä kahteen yhteiskuntatieteilijää, journalisti ja kokemusarvioitsija.

Tilaajien haastatteluaineisto koodattiin kokonaan. Tarkempaa analyysiä varten muodostettiin 15 teemakoodia (Saldana 2009). Runsaan 50 tekstisivun analyysiaineiston yleisimmät teemakoodit ovat (suluissa suhteellinen osuus analyysiaineistosta):

1. Palvelujen kilpailutus, hankintojen arviointi ja kehittäminen (21\%)

2. Tilaajien ja tuottajien yhteistyö (11\%)

3. Tilaajien tehtävät, toimintamahdollisuudet ja -rajoitukset (10\%)

4. Vallitsevien asumispalvelujen kriittiset tekijät (9 \%)

5. Palvelujen tuotantopolitiikka (7 \%)

6. Asumispalvelumarkkinat (7\%)

7. Tilaajien kuntoutusnäkemys (6\%)

Tutkimuksen esiymmärryksenä oli, että tilaajat soveltaisivat tilaaja-tuottajamallia melko yhdenmukaisesti. Yhtenevyys pelkistyi lähinnä tavoitteiden asettamiseen ja valvonnan kuvaamiseen. Tilaajahaastattelujen aineistolähtöinen sisällönanalyysi toi esiin yllättäviä ja merkittäviä eroja siinä, kuinka tilaajat tulkitsevat ja jäsentävät suhdettaan asumispalvelujen tuottajiin (Tuomi \&t Sarajärvi 2004). Kuvattujen erojen jäsentämisessä hyödynnettiin goffmanilaista kehysanalyysiä. Goffmanin (1986) mukaan sosiaalinen käyttäytyminen tapahtuu aina jossakin merkitysjärjestelmän luomassa kehyksessä. Kehyksen muuttuessa merkitysjärjestelmää luovat teot ja puheet tulkitaan uudella tavalla. Tilaaja-tuottajamallia on pidetty osana uutta julkisjohtamisen oppia (New Public Management, NPM, ks. Jylhäsaari 2009). Kehysanalyysin tulokset antavat aihetta pohtia, onko NPM:n soveltaminen yhdenmukaista. 


\section{Tilaajien tavoitteet asumispalvelutuottajille}

Haastattelujen perusteella kunnalliset tilaajapäälliköt ovat varsin tietoisia mielenterveysja päihdekuntoutujien yhteisöllisen asuttamisen riskeistä. Asumispalvelujen julkitavoitteena on vuosikymmenien ajan ollut asukkaiden kuntoutuminen. Palvelun käyttäjien enemmistön asuminen on silti muuttunut hyvin pitkäaikaiseksi. Tilaajat tulkitsevat tämän johtuvan asumispalvelujen toimintakäytännöistä.

(P)alveluntuottaja pystyy vaikuttaa siihen tilapäisen asumisen pituuteen sil omal tavotteellisel ja siihen pärjäämiseen tähtääväl toiminnallaan... Me (kunnan tilaajat, MS) ollaan tietosempia siitä, et mihin näitten ihmisten kohdalla pyritään, et on pyritty parantamaan tätä vuorovaikutusta näitten muitten asumispalveluitten kanssa, jotta tavallaan kunnan edustajana oltas tietosia siitä, että mitä näis paikois tehdään. Ja että oikeesti autettas niit ihmisii kuntoutumisessa. (Tilaajapäällikkö 1.)

Mitä täs itse oon miettiny jo pitkän aikaa, että... onks se ihan oikeesti niin, että palveluntuottajat haluavat selvittää juurta jaksaen asiakkaan kanssa, et mikä olisi hänelle se paras. Vai onko se vaan se, että kunhan se palvelu pyörii? Musta se on se kriittisin piste. (Tilaajapäällikkö 2.)

Jokainen tilaajapäällikkö esitti asumispalvelujen keskeisimpänä julkitavoitteena asukkaiden kuntoutumisen itsenäiseen tai itsenäisempään asumiseen. Tavoite on samanaikaisesti sosiaalihuollollinen ja asuntopoliittinen. Tutkijaryhmän yllätti se, että tavoitteita kuvatessaan haastateltavat eivät erityisemmin kiinnittäneet huomiota asukkaiden mielenterveyteen eivätkä päihteettömään elämään. Tämä olisi aikaisemmassa julkishallinnollisessa tavoitteenasettelussa ollut todennäköistä. Tilaajat eivät myöskään korostaneet asukkaiden yhteiskuntaan kiinnittymistä (integraatiota) eivätkä osallisuutta (inkluusiota), mikä olisi tyy- pillistä kriittisen sosiaalityön ja -politiikan viitekehyksille (Rowe 2015).

Asumispalvelujen tilaamista näyttäisi määrittävän ensisijaisesti kaksi toisiinsa yhdistyvää tekijää. Ensiksikin kunnalliset tilaajat pyrkivät kustannusten kasvun tehokkaaseen hillitsemiseen kunnallistalouden kriisin olosuhteissa. Asiakasvirtoja on tehostettu ja eri asumismuodoista oletetaan aiheutuvan erilaisia kustannusvaikutuksia. Mitä itsenäisemmin "kuntoutumisessaan edennyt" palvelun käyttäjä asuu, sitä vähemmän hänestä uskotaan aiheutuvan kunnalle kustannuksia.

Mistä tilaajat ovat omaksuneet itsenäisen asumisen retoriikan? Keskeisiä tekijöitä näyttäisi olevan ainakin kolme. Ensiksi, tilaamisen asiakirjoissa ja hallinnollisissa käytännöissä tilaamisen kohteina ovat asumisen eri tukimuodot. Mielenterveys- ja päihdekuntoutusta sekä niiden sisältötavoitteita ei tilata. Toiseksi, asumispalvelujen sääntely edellyttää hallinnollisesti riittävän yksinkertaista lähestymistapaa, mihin soveltuu ajatus palvelun käyttäjän portaittaisesta edistymisestä tuetummasta vähemmän tuettuun asumiseen. Asumismuodosta tulee keskeisin asukkaiden kuntoutumisen ja hyvinvoinnin peruste. Sen sijaan mielenterveyskuntoutujien elämänhallinnan tutkimusten ja päihdekuntoutuksen perusteiden mukaan yksilön tuen määrä vaihtelee ja jopa kasvaa kuntoutumista tukevissa elämänmuutoksissa (Deegan 1988; Perkinson et. al. 2014, 616-622; Repper \&t Perkins 2003, 48).

Kolmanneksi, asumispalvelujen tilaamisesta vastaavat kunnalliset virkamiehet ovat keskeisiä toimijoita kansallisen asunnottomuuden vähentämisohjelman paikallisessa soveltamisessa. Tämä on vahvistanut itsenäisen asumisen viitekehyksen asemaa. Yhdysvaltojen suurkaupungeissa kehitetty Asunto ensin -ohjelma perustui asunnottomuuden ehkäisyyn sekä kuntoutumisen tukemiseen ja osallisuuden vahvistamiseen. Myös kansalaisoikeudet olivat vahvasti esillä. Paradoksaalista on, että ongelmaltaan vähäisessä Suomessa pitkäaikaisasunnottomien asuttaminen on ollut ensisijaista päihde- ja mielenterveyskuntoutukseen nähden. (Rowe 2015; vrt. Karppinen 2014; Perälä \&t Jurvansuu 2016; Saari 2015, 161-212.) 
Kilpailutuksissa tilaajat ilmaisevat tavoitteensa: sen, mitä palvelun tuottajien tulisi edistää ja miten heidän tulisi organisoida toimintansa tavoitteiden saavuttamiseksi. Tavoitteet saavat konkreettiset reunaehtonsa hankintojen tarjouspyynnöissä. Tilaajilla ei ole kattavaa keinovalikoimaa palveluntuottajien toiminnan tuloksellisuuden varmentamiseksi. Lakisääteinen valvonta ei ole erityisen tehokas keino asumispalvelutuotannon tavoitteiden edistämisessä. Palveluyritysten palkitseminen bonus- ja sanktiojärjestelmän avulla on yleistymässä. Tässä ei ole mahdollista analysoida näitä keinoja tarkemmin.

Aiemmin mielenterveys- ja päihdekuntoutuksen hallinnollinen päätöksenteko ja asiantuntemus olivat samoissa käsissä. Tilaamisen aikakaudella hallinnollinen ja sisällöllinen asiantuntemus ovat erkaantuneet toisistaan. Esiteltävien kolmen kehyksen välillä ei tässä suhteessa ole ratkaisevaa eroa. Myös asiantuntemuksen kontekstit ovat dramaattisesti muuttuneet, sillä käyttäjien, perushenkilöstön, palvelutuotannon ja tilaamisen asiantuntemukset ovat entisestään erkaantuneet toisistaan.

Nyt on näitä aluejohtajia... he on harvoin substanssiosaajia. He hoitaa tätä verkostoa ja henkilöstöhallintoo ja suhteita kuntiin, vastaa kilpailutuksiin. Niin, he eivät osaa substanssista mitään. Sit heillä on yleensä mukana näis tapaamisissa joku yksikön johtaja tai joku muu, joka harvoin myöskään on siellä (asumispalvelujen, MS) arjessa. Tällä yksikön johtajalla ei oo sitä kulttuuria, ja tää aluejohtaja ei tiedä. Enhän määkään oo mikään substanssiasiantuntija. Se jää se keskustelu varmaan hyvin yleiselle tasolle. (Tilaajapäällikkö 3.)

Edellisessä otteessa tilaaja tunnistaa, ettei hänellä ole sisällöllistä asiantuntemusta mielenterveys- ja päihdekuntoutuksesta. Harvoilla tilaajapäälliköillä on mielenterveys- ja päihdealan erikoiskoulutusta tai työkokemusta. Tilaajapäällikön mukaan palvelutuottajien neuvottelukumppaneilla ei ole sen enempää ymmärrystä asumispalvelujen arjesta. Tutkijaryhmämme havaitsi, että erityisesti suurten asumispalveluyritysten alue- ja yksikönjohtajien tehtäväkentät ja toimenkuvat olivat etääntyneet kuntoutumista tukevan työn arjesta. Kehityssuunta on päinvastainen perinteisen tuloksekkaan mielenterveys- ja päihdetyön johtamisen kanssa, jossa sääntönä oli johtamisen läsnäolo työn arjessa.

\section{Asumispalvelujen tilaamisen kolme kehystä}

Haastateltavia pyydettiin asettamaan "kokemustaan vastaavaan ja arvostamaansa paremmuusjärjestykseen mielenterveys- ja päihdekuntoutujien asumisen palveluntuottajat: julkiset; järjestöjen ja yhdistysten; pienten ja keskisuurten (liikevaihto alle kolme miljoonaa euroa vuodessa) yksityisten sekä suurten palvelutuottajien ja muiden tuottamat asumispalvelut”. Haastatteluissa kysyttiin paremmuusjärjestyksen perusteita. Tutkijaryhmämme teki kiintoisan havainnon: osa tilaajista luotti julkisiin ja kolmannen sektorin palveluihin. Jotkut tilaajat luottivat pieniin ja keskisuuriin yrityksiin sekä kolmannen sektorin palveluihin. Yksi tilaajan edustaja korosti palveluntuottajan johtamistaitoja omistusmuotoa oleellisempana tekijänä. Nämä erot vaikuttivat tilaamisen kehysten rakentamiseen.

Haastattelujen analyysin lähtökohtana oli aineistolähtöinen sisällönanalyysi. Kehysanalyysi tuli tutkimusprosessiin sisällönanalyysin tuotettua tilaajien erilaiset tavat toimia ja tuottaa merkityksiä. "Kehystä" käytettiin edelleen tilaajien merkityksenannon ja toiminnan ymmärtämiseen sekä kehysten välisten oleellisten erojen osoittamiseen. Kehykset eroavat toisistaan ennen muuta niiden tavassa määrittää ja jäsentää tilaajien ja palvelutuottajien yhteistyötä. Julkishallinnollisessa kehyksessä (kehys I) luotetaan tilaajan ylivaltaan ja asiantuntemukseen. Tuotteistuksen kehyksessä (kehys II) luotetaan palvelun tuottajien asiantuntemukseen. Markkinaehtoisessa kehyksessä (kehys III) luotetaan kilpailuun ja vaihtoarvovälitteisiin mekanismeihin. Yhteistoiminnallinen kehys (kehys IV) on tutkijan konst- 
ruktio kehysten I - III vahvuuksista ja niiden puutteista. Tilaajien toiminnassa voi olla elementtejä eri kehyksistä

Kehys auttaa ymmärtämään, miksi tilaaja toimii ja tuottaa merkityksiä juuri kuin tekee. Kehykset heijastavat julkishallinnon ja kunnallisen sosiaalipolitiikan viimeaikaisia muutostrendejä: perinteisimmän julkishallinnollisen vahvan ohjauksen kehyksen ongelmat implikoivat tuotteistukseen ohjaavaa kehystä. Markkinaehtoinen vahvan ohjauksen kehys ilmentää julkishallinnon uusliberalisoitumista. Esittelen seuraavassa tiivistetysti kehysanalyysin tulokset.

\section{Julkishallinnollinen vahvan ohjauksen kehys}

Vahvan ohjauksen kehykselle on tyypillistä tilaajan retorisesti selkeä tietoisuus palvelutuotannon tavoitteista. Tavoitetietoisuus yhdistyy epäluottamukseen suuryritysten toimintaa kohtaan, mitä suuryritysten hegemonisoitunut asema entisestään vahvistaa. Tilaaja voi olla palvelun tuottajan ja tilaajan kaksoisroolissa, mikä pitää yllä tilaajan paternalistista oikeassa olemisen uskoa: "tää meijän toiminta on parempaa kuin yksityisten palveluntuottajien, koska me yritetään oikeesti kuntouttaa ihmisii asumaan itsenäisesti" (tilaajapäällikkö 1). Kehyksessä ohjaamisen keinoina ovat palvelutuottajien kontrolli ja valvonta sekä kilpailutuksen sopimusteknisten ehtojen toistuva tarkistaminen.

Nykytilanteessa perinteisen vahvan ohjauksen soveltaminen synnyttää lähes väistämättömästi epäluottamusta: voittoa tavoitteleva yritystoiminta karsastaa julkisen toimijan kaksoisroolia tilaajana ja tuottajana. Kolmannen sektorin toimijat eivät katso hyvällä, että heidän on puettava kansalaisyhteiskunnasta kumpuavat arvotietoiset lähtökohtansa markkinaehtoisuuden kaapuun. Epäluottamuksesta aiheutuvat yhteistyön ongelmat johtavat tilaajien ja tuottajien vastavuoroiseen osaoptimointiin. Tämä heikentää ratkaisevasti tilaajan tavoittelemaa palvelukokonaisuuksien rakentamista. Vahvan ohjauksen avulla voidaan pyrkiä sääntelemään palvelutuottajien voiton tavoittelua ja aktivoimaan palveluntuottajia asiakkaiden laitostumisen ehkäisemiseksi. Toimivaa asumispalvelujen kokonaisuutta ei voida nykyoloissa rakentaa vahvan ja paternalistisen ohjauksen varaan. (Vrt. Le Grand \& New 2015.)

\section{Tuotteistukseen ohjaava kehys}

Tuotteistukseen ohjaavassa kehyksessä vältytään paternalismilta. Tilaaja ohjaa palvelutuotantoa pilkkomalla palvelukokonaisuuksia erillisiksi tuotteiksi. Asumispalvelut tavaramuotoistetaan hinnoittelun ja hinnalla kilpailemisen avulla. Yhden palvelukokonaisuuden pilkkominen yli kymmeneksi erillistuotteeksi johtaa uuteen laadulliseen muutokseen. Tuotteistukseen ohjaava kehys voidaan ymmärtää vastausyrityksenä perinteisen vahvan ohjauksen synnyttämään tilaajien ja tuottajien väliseen epäluottamukseen. Käytännössä kehys muodostuu olosuhteissa, missä julkista asumispalvelutuotantoa ei ole rakennettu tai siitä on luovuttu.

Ohjauksen keinoina ovat palvelutarpeen analyysi, kehittynyt tarveharkinta ja eriytetty tuotteistus. Monituotemarkkinoilla tilaajan tehtävänä on toimia ostajana ja palveluntuottajien myyjinä. Kehyksessä luottamuksen uskotaan rakentuvan jättämällä tuottajille avoin pelikenttä. Miksi tuottaja sitoutuisi palvelukokonaisuuksien - muun kuin oman monopolistisen palvelukonserninsa - rakentamiseen? Tilaajien sinänsä tarpeellinen antipaternalistinen ennakkoasenne voi synnyttää katteetonta hyväuskoisuutta. Paradoksaalisesti, kun paternalismista ja vahvasta ohjauksesta luovutaan, voidaan samalla joutua luopumaan palvelujärjestelmän rakentamisesta. Tuotteistus voi edistää laadukkaiden palvelujen muodostumista, mutta ilman vahvaa ohjausta ja sääntelyä se johtaa väistämättä pirstaleiseen toimintajärjestelmään.

Tuotteistukseen ohjaavan kehyksen vahvuutena on mahdollisuus luoda toimintaympäristö, missä useammat palveluntuottajat eri toimintafilosofioineen ja tavoitteineen voivat toimia rauhanomaisesti rinnakkain. Julkistaloudellisesti ja asukkaiden kuntoutumisen 
kannalta koordinoidun kokonaisuuden menettäminen on kohtuuton kustannus.

\section{Markkinaehtoinen vahvan ohjauksen kehys}

Kehys voidaan ymmärtää vastausyrityksenä palvelujärjestelmän pirstaloitumiseen ja epäluottamuksen rakentumiseen. Sitä luonnehtii pyrkimys kehittää kustannus- ja vaikuttavuustehokas palvelukokonaisuus markkinoiden aikakaudelle. Toiminnan tuloksellisuutta jäsennetään mitattavina suureina (tuloksellisuusprosentteina) ja sen arvoa määritetään ensisijaisesti vaihtoarvoina, taloudellisina palkintoina ja sanktioina. Markkinaehtoiselle kehykselle otollisissa olosuhteissa julkisia palveluja ei ole tai niitä ollaan purkamassa. Julkisten palvelujen liikelaitostamiseen voidaan soveltaa samoja markkinaehtoisia periaatteita.

Hankintamenettelyssä tilaajat asettavat mitattavan tuloksellisuuden perusteet. Palveluntuottajat ilmoittavat tarjoamansa palvelun tulostavoitteen, jota hinnan ohella käytetään tarjouspyyntöjen keskinäisessä vertailussa. Tuloksellisuuden arviointiin sovelletaan bonuksia ja sanktioita. Saavuttaessaan tulostavoitteet palveluntuottaja saa lisämäärärahaa tai aikaisempaa sopimuskautta jatkavan lisäajan, "optiovuoden". Mikäli tuottaja ei saavuta tulostavoitteita, yritys voi joutua taloudellisesti vastuuseen sopimusrikkomuksesta. Tilanne asettaa (usein paikalliset) pienet ja keskisuuret tuottajat eriarvoiseen asemaan suuryritysten kanssa, sillä pienille toimijoille taloudelliset korvausvaateet muodostuisivat kohtalokkaiksi.

Tilaajat uskovat palveluntuottajien omaksuvan tehokkaamman ja tuloksellisemman toimintakulttuurin bonus- ja sanktiojärjestelmän avulla (vrt. Lehto \&t Tynkkynen 2013). Tuloksellisuustavoitteita ja niiden toteutumista on tosin arvioitava jatkuvasti, jolloin kehyksen mukaisesti tilaajien ja tuottajien välinen oppimisprosessi tulee mahdolliseksi ja jopa välttämättömäksi. Tässä mielessä kehys edustaa paternalismin ja antipaternalismin välimuotoa.

Ensituntumalta kehys vaikuttaa toimival- ta. Se luo selvän mahdollisuuden edellä esitettyjen kehysten karikkojen väistämiseen. Tilaaja antaa antipaternalistisesti tuottajien määritellä itse tulostavoitteensa. Menestyäkseen kilpailuolosuhteissa jokaisen palvelun tuottajan on kuitenkin arvioitava mahdollisuutensa epärealistisesti - tai hyväksyä, että jotkut kilpailijoista tekevät niin. Tilaajan tavoittelema palvelun tuottajien organisatorinen ja työkulttuurinen muutosprosessi voisi parhaimmillaan johtaa toimivaan oppimisprosessiin. Bonus- ja sanktiojärjestelmän käyttö tuloksellisuuden keinona viivästyttää yhteistä oppimisprosessia. Voidaanko yhteistä oppimista saada aikaan yksinkertaisemmilla ja helpommilla tavoilla?

Markkinaehtoisen kilpailun olosuhteissa suurena vaarana on arvotietoisuuden menettäminen. Bonusten nykyinen käyttö vahvistaa palveluyritysten taloutta mutta ei palvelun käyttäjien taloudellista asemaa. Palvelun käyttäjien itsenäinen elämä on edelleen pääsääntöisesti mahdollista vain huonoosaisuuden mittapuilla. Ilman käyttäjien talouden kohentumista "itsenäinen asuminen" muuttuu lähinnä tekniseksi toimenpiteiden sarjaksi. Oikeudenmukaisuutta vahvistavat hyvinvointipoliittiset tavoitteet eivät sovi kehyksen raameihin. Kuvaavaa on, että kehyksen omaksunut tilaaja piti mielenterveyskuntoutujien työtoimintaa ja työosuusrahaa epäoikeudenmukaisena toimintana ja tulonsiirtona suhteessa työttömiin.

Kehys tuo esiin, kuinka hyvinvointitalouden suuntaa muutetaan markkinaehtoisen ohjauksen avulla. Palvelun tuottajaa palkitaan erityisesti siitä, että yrityksen harjoittama toiminta on tuloksellista ja tavoitteellista. Eikö tämän tulisi sisältyä itse hankinnan lähtökohtiin? Miksi vain palvelua tuottavaa yritystä tulisi palkita mielenterveys- ja päihdekuntoutusta edistävästä toiminnasta, kun mielenterveys- ja päihdekuntoutujan oma panos on ratkaiseva hänen kuntoutumisessaan (vrt. Hyväri 2001; Rissanen 2015)? Asumispalvelujen henkilöstön osuutta kuntoutumisen tukemisessa ei tule mitenkään vähätellä. Markkinaehtoisessa kehyksessä tilaaja palkitsee yritystä ja sen omistajia, ei kuntoutumista 
tukenutta henkilöstöä eikä kuntoutumistyön tehneitä palvelun käyttäjiä.

Markkinaehtoisen viitekehyksen avulla ei suunnisteta kohti tilaajien asettamia tavoitteita. Itsenäinen asuminen - ja lisään: itsenäinen elämä ${ }^{3}$ - koskevat asumispalveluja käyttävien mielenterveys- ja päihdekuntoutujien asemaa yhteiskunnassa. Markkinaehtoisen kehyksen avulla ei vahvisteta kuntoutujien elämän haltuunottoa $^{4}$ eikä heidän osallistumistaan yhteiskuntaan. Molemmat ilmiöt ovat merkittävässä määrin myös taloudellisia.

\section{Yhteistoiminnallinen kehys tutkijan konstruktiona}

Tilaamisen kehysten hallinnollis-juridiseen hankintaosaamiseen ei sisälly riittävää ymmärrystä hankittavista palveluista ja tuotteista. Tilaajat eivät saavuta asumispalvelujen tavoitteita hallinnollisen asiantuntijaosaamisen avulla. Yksinkertaisin ratkaisu voisi olla hallinnollisen ja sisällöllisen asiantuntemuksen yhdistäminen tilaajapäällikkö ja johtava lääkäri/ päihdepalvelujohtaja -työparin tai moniammatillisen pienryhmän avulla. Jälkimmäistä on joissakin kunnissa jo kokeiltu. Eduistaan huolimatta toimintatavassa sivuutetaan palvelun käyttäjät ja perustason työntekijät "itsenäisen asumisen ja elämän" asiantuntijoina. Jo Mieli 2009 -toimintaohjelmassa suositeltiin mielenterveys- ja päihdekuntoutujien kokemusasiantuntemuksen käyttöä palvelujen suunnittelussa ja arvioinnissa (Sosiaali- ja terveysministeriö 2009).

Mitä yhteistoiminnallinen kehys voisi tarkoittaa? Siinä asumispalvelujen tilaajien, tuottajien ja käyttäjien yhteistoiminta koskisi palvelujen suunnittelua, arviointia, kehittämistä ja tutkimusta - sekä niiden tilaamista. Kaikkien asianosaisten ryhmien asiantuntemuksen käyttö on yhteistoiminnallisen kehyk- sen keskeinen peruspilari. Sen rakentamisessa otetaan käyttöön edellä analysoitujen kehysten vahvuudet: palvelujärjestelmän rakentaminen (kehys I); luottamuksen rakentaminen tilaajien ja tuottajien välille (kehys II) ja sen laajentaminen perustyöntekijöihin ja palvelun käyttäjiin; ja tuloksellisuus (kehys III) ja sen laajentaminen niin, että tuloksellisuudesta palkitaan myös perustyöntekijöitä ja palvelun käyttäjiä.

Kehyksen toteutuskeinoina voisivat olla tilaajien, tuottajien, käyttäjien ja muiden asianosaisten kehittämis- ja arviointifoorumit. Niissä määritellään palvelukokonaisuuksia, tunnistetaan palveluketjujen aukkoja sekä asianosaisryhmien yleisiä ja ryhmäkohtaisia intressejä. Kehystä olisi syytä koetella käytännössä.

\section{Johtopäätökset: Standardisoinnista kohti yhteistoiminnallista sotea}

Vuosikymmen sitten kolmannen sektorin asumispalvelut olivat keskimäärin neljä kertaa laadukkaampia kuin voittoa tavoittelevien yritysten palvelut (Salo \&t Kallinen 2007). Vain noin 15 prosenttia asumispalveluyksiköistä saavutti edes kohtuullisesti asukkaiden kuntoutumista tukevia tuloksia. Palvelujen markkinaehtoistuminen ja pyrkimys kustannustehokkuuteen eivät ole parantaneet palvelun laatua. Kuntoutumistulokset ovat vaarassa heikentyä, mikäli tulostavoitteisella ja hallinnollisella itsenäisen asumisen retoriikalla tähdätään julkistalouden säästöihin ja suuryritysten markkinaosuuksien vahvistamiseen, mistä asumispalvelujen työntekijät esittivät tutkimushaastatteluissa vakavan huolensa.

Näyttää siltä, että kilpailutuksen merkitystä palvelujen laadun, kustannustehokkuuden ja tuloksellisuuden varmentamiseksi on yliarvioitu. Laajan Ison-Britannian sosiaali-, terveys- ja koulutuspalvelujen tilaamista selvittä-

\footnotetext{
3 Itsenäinen asuminen ei ole kuntoutujan yhteiskuntaan osallistumisen välttämätön ehto. Italiassa mielenterveyskuntoutujat työskentelevät sosiaalisissa yrityksissä ja asuvat tuetuissa ryhmäkodeissa (Rotelli 1993). Toisaalta itsenäinen asuminen ei ole itsenäisen elämisen riittävä ehto. Isossa-Britanniassa siirryttiin itsenäisen elämän viitekehykseen jo 1990-luvun alussa (Beresford \& Salo 2008).
}

\footnotetext{
${ }^{4}$ Englanninkielen käsitteelle 'recovery' ei ole toimivaa suomennosta. Suomennan sen 'oman elämän haltuunotoksi' - ei 'toipumiseksi' siinä mielessä, ettei mielenterveys- tai päihdeongelmalla olisi enää vaikutusta yksilön elämään (vrt. Repper \& Perkins 2003, ix).
} 
neen tutkimuksen mukaan managerialistisessa tilaamisessa ei ole onnistuttu rakentamaan toimivaa yhteistyötä "eturivin ammattilaisiin" (Hudson 2011). Suomessa ei tutkimuksellisesti ole osoitettu kilpailutuksen parantaneen asumispalvelujen laatua, saati vahvistaneen niiden käyttäjien asemaa. Tämä ei ole yllättävää, sillä kilpailutuksissa palvelujen laadun kehittämisellä on ollut marginaalinen merkitys kustannussäästöjen tavoitteluun nähden (Suurmäki 2011; vrt. Brennan et.al. 2012; Newman et.al. 2012).

Palvelutuottajien asettaminen kilpailutuksissa samalle viivalle on johtanut palvelujen standardisointiin. Monet standardeista poikenneet keskisuuret ja pienet palvelutuottajat ovat kadonneet palvelutuotannon kentältä. Standardisointi ei ole paras vaihtoehto palvelujen laadun ja tuloksellisuuden turvaamiseksi. Historiallisesti merkittävä enemmistö mielenterveys- ja päihdepalvelujen hyvistä käytännöistä on poikennut radikaalisti oman aikansa standardipalveluista (Anderson et.al. 1999; Dell'Acqua 1995; Haarakangas 2002; Mezzina 2000; Seikkula \&t Alakare 2007). Tällä hetkellä kustannustehokkaat suuryritykset hyötyvät standardisoinnista. Kilpailutus näyttää soveltuvan hyvin modernin kapitalismin uusliberalistisen kriisin ja siitä aiheutuneen julkistalouden kustannussäästöjen työkaluksi. (Blyth 2013; Duménil \& Lévy 2011.)

LeGrandin (2007) mukaan palvelujen hankinta voi perustua a) luottamukselle ammattilaisiin ja managereihin; b) hallintovallan käskyille ja kontrollille; c) käyttäjien etujen ajamiselle; tai d) valinnalle ja kilpailulle. Hankintalain soveltaminen sosiaali- ja terveyspalveluihin on johtanut siirtymään a:sta b:hen ja sitten siirtymään b:stä d:hen. (Vrt. Junnila et al. 2012; Lehto \&t Tynkkynen 2013.) Kehysanalyysi antaa vakavan aiheen epäillä, ettei siirtymä professionaalisilta osaajilta hallintomanagereille ole onnistunut. LeGrandin analyysiä voidaan hyödyntää yhteistoiminnallisten käytäntöjen kehittämisessä ja managerien tai eturivin ammattilaisten hegemonian välttämisessä. Sosiaali- ja terveyspalvelujen keskeinen ongelma ei ole osaamisen eikä asiantuntemuksen puute, vaan tilaajien, tuottajien, työntekijöiden ja käyttäjien todellisuuksien ja merkitysrakenteiden yhä jyrkempi etääntyminen toisistaan.

Sosiaali- ja terveydenhuollon rakenneuudistuksen (sote) lähtökohtana oli kansalaisten hyvinvointierojen tasaaminen lisäämällä julkisten sosiaali- ja terveyspalvelujen saatavuutta. Viime aikoina on keskustelun keskiössä ollut itsehallintoalueiden määrä ja asiakkaiden valinnanvapaus. Hankintakäytäntöjen uudistaminen saattaa tulla seuraavana vuoroon. Palveluiden nykyisestä pirstaloitumisesta huolimatta vastuu palvelujärjestelmästä siirtynee maakunnallisille itsehallintoalueille. Mahdollista on, että rajapinta julkisten ja yksityisten palvelujen välillä häviää - ainakin siinä määrin kuin julkisia sosiaali- ja terveyspalveluita liikelaitostetaan ja yhtiöitetään. (HE 328/2010; HE 324/2014; Kokko et al. 2009; Komulainen 2010.)

Mitä tarkoittaa sote-itsehallintoalueilla tapahtuva julkishallinnollinen ohjaus jo vahvasti markkinaehtoistuneen palvelutuotannon olosuhteissa? Mikäli sosiaali- ja terveyspalvelujen tuotannolla pyritään edistämään tasaarvoa ja vahvistamaan oikeudenmukaisuutta, nykyiset tilaamisen kehykset eivät ole riittäviä eivätkä erityisen toimivia. Tilaajien keskittyminen kilpailutuksiin tulee entisestään heikentämään palvelujärjestelmää. Tilaamisen kehyksissä ei ole hyödynnetty asiakkaiden eikä palvelujen perushenkilöstön asiantuntemusta. "Itsenäisen asumisen ja elämän" tavoitteet ovat vaarassa jäädä retoriikaksi. Kilpailutusta luotettavampi tae palvelujen laadulle ja oikeudenmukaiselle hyvinvointipolitiikalle on kaikkien asianosaisryhmien yhteistoiminta ja sitä edistävien käytäntöjen kehittäminen. Julkinen valta voi tulevaisuudessakin velvoittaa yhteistoimintaan. Osallistumisen tuloksellisuus riippuu kuitenkin siitä, muodostuuko yhteistoiminnassa kaikkia asianosaisryhmiä tyydyttäviä win-win-asetelmia. 


\section{Tiivistelmä}

Artikkelissa tarkastellaan, millaisia tavoitteita kunnalliset tilaajat asettavat asumispalveluille. Millaisia tilaamisen viitekehyksiä on tunnistettavissa asumispalvelujen tilaajien teemahaastattelujen perusteella?

Analyysin tuloksena tunnistetaan kolme kehystä: julkishallinnollinen vahvan ohjauksen, tuotteistukseen ohjaava ja markkinaehtoinen vahvan ohjauksen kehys. Kehyksiä yhdistää se, ettei hankintaosaamiseen sisälly riittävää ymmärrystä tilattavista palveluista ja tuotteista. Tilaajien tavoitteiden saavuttaminen edellyttäisi asiantuntemuksen uutta jäsentämistä. Palvelun käyttäjien itsenäisen asumisen ja elämän sekä henkilöstön asumisen tuen asiantuntemusta tarvitaan palvelujen tilaamisessa ja näin ollen myös sosiaali- ja terveydenhuollon uudistuksessa - esimerkiksi artikkelissa luonnostellun neljännen, yhteistoiminnallisen kehyksen mukaisesti.

Kilpailutus ei ole toimiva väline asumispalvelujen tilaamisessa. Sen merkitystä palvelujen laadun, kustannustehokkuuden ja tuloksellisuuden saavuttamisessa on yliarvioitu. Kilpailutus ei ole suoraan vaikuttanut palvelujen laadun eikä palvelujen käyttäjien aseman kohentumiseen, mihin yhteistoiminnallinen kehys antaa uusia mahdollisuuksia. Avainasemassa on tilaajien aloitteellisuus. Julkisen ohjauksen tehtävänä on velvoittaa kaikkia asianosaisryhmiä tyydyttävään yhteistoimintaan.

Avainsanat: asumispalvelujen tilaaminen, mielenterveys- ja päihdekuntoutus, yhteistoiminnallinen kehys

\section{Abstract}

Frameworks of Commissioning Residential Facilities for Mental Health and Drug Service Users. In Search of a Collaborative Framework.

This article analyzes the goals that commissioners of residential facilities for mental health and drug service users try to achieve. Are there specific frameworks of commissioning which can be recognized from analysis of interviews with commissioners? The research material used in this analysis is based on field work in three different parts of Finland.

The article recognizes three frameworks of public steering: a strong traditional commissioning; a new model for commodification of services and a strong market based commissioning. The critical common denominator of these frameworks is that the commissioners do not have adequate understanding of the services and the contexts of service provision which they are obliged to commission and purchase. To achieve the goals set by the commissioners, a new model of collaborative framework is duly required - this framework puts stronger emphasis on the expertises of users and ground floor staff. The commissioners play a key role in forming new alliances between private and other service providers, the ground floor staff, the service users and other stakeholders.

Key words: commissioning, housing services for mental health and drug service users, collaborative framework

Markku Salo, YTT, vastaava tutkija, toimittaja, Asumispalvelujen musta laatikko -hanke

\section{Lähteet}

Anderson D, McGovern J, Dupont R (toim.) (1999) The Origins of the Minnesota Model of Addiction Treatment - A First Person Account. Journal of Addictive Diseases 18, 1, 107-114. 
Beresford P, Salo M (2008) Kokemuksen muodonmuutos. Kohti palveluiden käyttäjien omaa tutkimustoimintaa. Mielenterveyden keskusliitto, Helsinki.

Blyth M (2013) Austerity: The History of a Dangerous Idea. Oxford University Press, New York.

Brennan D, Cass B, Himmelweit S, Szebehely M (2012) The Marketisation of Care: Rationales and Consequences in Nordic and Liberal Care Regimes. Journal of European Social Policy 22, 4, 377-391.

Deegan P (1988) Recovery: The Lived Experience of Rehabilitation. Psychosocial Rehabilitation Journal 11, 4, 11-19.

Dell'Acqua G (1995) Trieste Twenty Years After: From the Criticism of Psychiatric Institutions to Institutions of Mental Health. http://www.triestesalutementale.it/english/archive.htm

Duménil G, Lévy D (2011) The Crisis of Neoliberalism. Harvard University Press, Cambridge, MA.

Eräsaari L (2006) New Public Management on julkisen sektorin vääryyksien isä. Teoksessa Helne T, Laatu M (toim.) Vääryyskirja. Kelan tutkimusosasto, Helsinki.

Goffman E (1986) [1974] Frame Analysis: An Essay on the Organization of Experience. Northeastern University Press, Boston.

Haarakangas K (toim.) (2002) Mielisairaala muuttuu: Keroputaan sairaalan kokemuksia psykiatrisen hoidon kehittämisessä: avoimen dialogin hoitomalli. Suomen kuntaliitto, Helsinki.

HE 328/2010. Hallituksen esitys eduskunnalle laiksi sosiaali- ja terveydenhuollon järjestämisen kehittämisestä vuosina 2011-2014.

HE 324/2014. Hallituksen esitys 2014 eduskunnalle laiksi sosiaali- ja terveydenhuollon järjestämisestä sekä eräiksi siihen liittyviksi laeiksi.

Hirsjärvi S, Hurme H (2001) Tutkimushaastattelu: teemahaastattelun teoria ja käytäntö. Yliopistopaino, Helsinki.

Hudson B (2011) Ten Years of Jointly Commissioning Health and Social Care in England. International Journal of Integrated Care 11, 7, 1- 9.

Hyväri S (2001) Vallattomuudesta vastuuseen - kokemuksen politiikan sankaritarinoita. Vankeinhoidon koulutuskeskuksen julkaisu 3. Tietosanoma Oy, Helsinki.

Junnila M, Aho T, Fredriksson S, Keskimäki I, Lehto J, Linna M, Miettinen S, Tynkkynen L-K (toim.) (2012) Sitä saa mitä tilaa. Tilaaja-tuottaja-toimintatavan kehittyminen sosiaali- ja terveyspalveluissa. Raportti 42. Terveyden ja hyvinvoinnin laitos, Helsinki.

Jylhäsaari J (2009) Johtamisen muutos kuntien perusterveydenhuollon organisaatioissa. Tietoista uu- distamista vai realiteetteihin sopeutumista? Acta Wasaensia 212. Vaasan yliopisto, Vaasa.

Karppinen J (2014) Väliraportti 2012-2013. Pitkäaikaisasunnottomuuden vähentämisohjelma (Paavo 2) 2012-2015. Ympäristöministeriö, Helsinki.

Kokko S, Heinämäki L, Tynkkynen L-K, Haverinen Ri, Kaskisaari M, Muuri A, Pekurinen M, Tammelin M (2009) Kunta- ja palvelurakenneuudistuksen toteutuminen. Kuntakysely sosiaali- ja terveyspalvelujen järjestämisestä ja tuottamisesta. Raportti 36. Terveyden ja hyvinvoinnin laitos, Helsinki.

Komulainen M (2010) Ulkoistaminen kunnissa. Oikeudellinen tutkimus ulkoistamisen ilmenemismuodoista ja vaikutuksista sekä ulkoistamisen rajoituksista ja sille asetettavista vaatimuksista yhtenä kunnallisten palvelujen tuottamismuotona. Acta 222. Suomen Kuntaliitto, Helsinki.

Krachler N, Greer I (2015) When Does Marketisation Lead to Privatisation? Profit-Making in English Health Services After the 2012 Health and Social Care Act. Social Science \&t Medicine 124, 215-223. L1501/1992. Laki julkisista hankinnoista.

L733/1992. Laki sosiaali- ja terveydenhuollon suunnittelusta ja valtionosuudesta.

Le Grand J (2007) The Other Invisible Hand: Delivering Public Services through Choice and Competition. Princeton University Press, Princeton, NJ. and Oxford.

Le Grand J, New B (2015) Government Paternalism: Nanny State or Helpful Friend? Princeton University Press, Princeton, NJ. and Oxford.

Lehto J, Tynkkynen L-K (2013) Älykkäästi suunnitellut sosiaali- ja terveydenhuollon markkinat? Yhteiskuntapolitiikka 6/2013.

Mezzina R (2000) Deinstitutionalization and Community: A Possible Restitution. Building Bridges Conference, Auckland, March 29-31, 2000. http:// www.triestesalutementale.it/english/archive.htm

Newman M, Bangpan M, Kalra N, Mays N, Kwan I, Roberts T (2012) Commissioning in Health, Education and Social Care. Models, Research Bibliography and In-depth Review of Joint Commissioning between Health and Social Care Agencies. EPPI-Centre Report 2007. University of London, London.

Perkinson R, Jongsma A, Bruce T (2014) The Addiction Treatment Planner: Includes DSM-5 Updates. 5th Edition. Wiley, Hoboken, NJ.

Perälä R, Jurvansuu S (2016) Politiikasta käytännöksi. Asunto ensin -politiikan arkea asumisyksiköiden työntekijöiden kertomana. Yhteiskuntapolitiikka 5/2016.

Repper J, Perkins R (2003) Social Inclusion and Re- 
covery. A Model for Mental Health Practice. Baillière Tindall, London.

Rissanen P (2015) Toivoton tapaus? Autoetnografia sairastumisesta ja kuntoutumisesta. Kuntoutussäätiö, Helsinki.

Rotelli F (1993) La Foresta di Pietra - conferenza dei servizi di salute mentale trieste, 13/14 maggio 1992. Edizioni e, Trieste.

Rowe M (2015) Citizenship \& Mental Health. Oxford University Press, Oxford.

Saari J (2015) Huono-osaiset. Elämän edellytykset yhteiskunnan pohjalla. Gaudeamus, Helsinki.

Saldana J (2009) The Coding Manual for Qualitative Researchers. Sage Publications, Thousand Oaks, CA.

Salo M, Kallinen M (2007) Yhteisasumisesta yhteiskuntaan? Mielenterveyskuntoutujien asumispalveluiden tila ja tulevaisuus. Mielenterveyden keskusliitto, Helsinki.

Seikkula J, Alakare B (2007) Open Dialogues. Teoksessa Stastny P, Lehmann P (toim.) Alternatives Beyond Psychiatry. Peter Lehmann Publishing, Berlin, Eugene, Shrewsbury.

Sosiaalihuoltolaki 710/1982.
Sosiaali- ja terveysministeriö (2009) Mielenterveys- ja päihdesuunnitelma. Mieli 2009 -työryhmän ehdotukset mielenterveys- ja päihdetyön kehittämiseksi vuoteen 2015. Sosiaali- ja terveysministeriö, Helsinki.

Suurmäki J (2011) Hulluuden markkinat. Tutkimus yksityisen sosiaalipalvelutuottajan asemasta muuttuvassa markkinaympäristössä. MBA-opinnäyte. Yrittäjyyden Osaamiskeskus, Mikkeli.

Tuomi J, Sarajärvi A (2004) Laadullinen tutkimus ja sisällönanalyysi. Tammi, Helsinki.

\section{Kuntoutussäätiö}

